\title{
FAKTOR-FAKTOR YANG MEMPENGARUHI MASYARAKAT KOTA PADANG DALAM MEMILIH APLIKASI BUKALAPAK, SHOPEE DAN TOKOPEDIA DIMASA PANDEMI COVID19
}

\author{
Raftul Fedri. Tri Irfa Indrayani. \\ ${ }^{1,2}$ Fakultas Ekonomi Universitas Muhammadiyah Sumatera Barat \\ raftulclassic@gmail.com triirfaindrayani1@gmail.com
}

\begin{abstract}
This study aims to determine consumer orientation in choosing online shopping applications on the Tokopedia, Shopee and Bukalapak applications, as well as to find the factors that influence it. The type of research is a descriptive study where the respondents are the people of the city of Padang with a population of 80 people with a sampling technique using non-probability sampling method with a total sample of 60 people. From the results of the study, it was found that the online shopping market through an online application during the Covid19 pandemic which was widely used by the public was the Shoopee application. The factor that was excluded from the analysis of the factors in this research was the cultural factor. The eigenvalue of component 1 is 1.304 or $>1$ and is able to explain $43.466 \%$ variation
\end{abstract}

Keywords: Market place, Online Transaction, Online Application, e-commerce

\begin{abstract}
ABSTRAK :Penelitian ini bertujuan untuk mengetahui orientasi konsumen dalam memilih aplikasi belanja online pada aplikasi Tokopedia, Shopee dan Bukalapak, sekaligus menemukan faktor-faktor yang mempengaruhinya. Jenis penelitian adalah Studi deskriftif dimana Responden adalah masyarakat kota Padang dengan populasi berjumlah 80 orang dengan teknik pengambilan sampel menggunakan metode non probability sampling dengan jumlah sampel sebanyak 60 orang. Dari hasil penelitian diperoleh pasar belanja online melalui aplikasi online dimasa pandemi Covid19 yang banyak digunakani oleh masyarakat adalah aplikasi Shoopee.Faktor yang dikeluarkan dari analisis faktor dalak penelitian ini adalah faktor budaya..Terdapat 1 faktor yang terbentuk dari 3 variabel yang di analisis,dengan. Nilai Eigenvalue komponen 1 sebesar 1,304 atau $>1$ dan mampu menjelaskan $43.466 \%$ variasi
\end{abstract}

Kata Kunci: Market place, Transaksi Online,Aplikasi Online, e-commerce

\section{A. PENDAHULUAN}

Dampak yang terjadi akibat pandemi Virus Covid 19 berakbibat memburuknya pertumbuhan ekonomi dan bisnis diprediksi merosot hingga 3\% ditahun 2020 ini.

Hal ini dipicu oleh adanya pembatasan sosial besar-besaran diseluruh Indonesia dan karantina wilayah guna meredam penularan virus yang menyebabkan menurunya aktivitas ekonomi dan perdangangan internasional, nasional maupun di tingkat daerah. Sektor perdagangan dan tingkat konsumsi masyarakat secara menyeluruh serta perilaku pembelian juga terkena dampaknya .Namun di sisi lain peluang yang muncul dengan adanya pandemi ini di aktivitas transaksi bisnis online tetap berjalan dan merupakan media solusi bagi masyarakat akibat pembatasan sosial tersebut.

Di daerah Kota Padang Sumatera Barat penggunaan media transaksi online sudah mulai menyemarak dan ramai digunakan oleh masyarakat dalam waktu 5 (lima) tahun terakhir ini. Hal ini ditandai dengan bermunculannya kantor provider penyedia bisnis layanan online seperti Bukalapak, Tokopedia dan Shopee yang aplikasinya dimanfaatkan oleh konsumen /masyarakat selama pandemi dalam kegiatan jual/beli barang-barang. peluang ini tampak nyata hasilnya dibarengi oleh antusias konsumen/seller yang beraktivitas melalui berbagai promosi melalui komentar baik secara positif dan secara direct message antar pelaku bisnis jual beli online. Aplikasi Bukalapak,Tokopedia dan Shopee merupakan aplikasi E-Commerce yang sangat potensial sebagai media yang berperan dalam situasi masa pandemi Covid19, khususnya di aspek belanja online, namun sebelum hal itu berkembang luas harus dipahami dulu faktor-faktor apa yang menyebabkan pemicu konsumen dalam memilih aplikasi market place tersebut. 
Gambar 1:Situs online yang dipilih oleh konsumen di Kota Padang

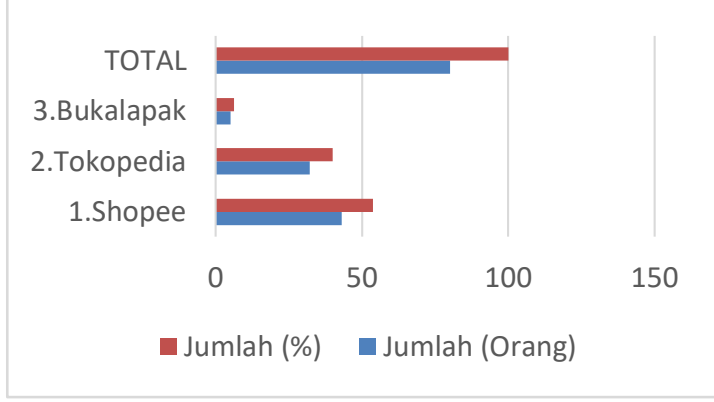

Berdasarkan data diatas dapat dilihat persaingan 3 aplikasi online terbesar di Indonesia untuk daerah kota padang dari 80 orang populasi berdasarkan hasil survey awal terlihat aplikasi shopee menjadi situs pilihan terbesar di Kota padang dengan tingkat rata-rata persentase pilihan bagi konsumen mencapai 53\% disusul oleh Tokopedia dengan jumlah $40 \%$ dan Bukalapak dengan tingkat pilihan sebanyak $6 \%$ lebih.

Permasalahan yang terjadi dimasa yang akan datang adalah bagaimana persaingan aplikasi onlineshop ini dapat memicu peluang munculnya strategi penjualan baru yang dapat selalu mempertahankan/meningkatkan tingkat penjualan dan melihat tingkat pola konsumsi masyarakat yang bermacam ragam, memuaskan keinginan konsumen yang berhubungan dengan strategy pemasaran online yang peluangnya dapat dilihat dari perilaku konsumen dimasa pandemi sekarang ini.dalam Penelitian ini akan menjawab pertanyaan penelitian antara lain :

1.Faktor-Faktor apa saja yang mempengaruhi konsumen dalam memilih dari 3 (tiga) aplikasi belanja online (Bukalapak, Shopee, dan Tokopedia), 2.bagaimana perilaku konsumen belanja online di kota Padang pada masa pandemi Covid 19, 3.Faktor yang manakah yang paling dominan mempengaruhi konsumen dalam memilih aplikasi tersebut?

\section{B. KAJIAN LITERATUR}

Menurut Kotler (2011) :faktor-faktor yang dapat mempengaruhi plihan konsumen ketika berbelanja/bertransaksi bisnis terdiri dari empat aspek penting yaitu: aspek budaya, aspek sosial, aspek individu (personal) dan aspek lingkungan. Dimana keempat aspek ini bersinergi melalui proses online shoping dan keputusan konsumen dalam menentukan pilihan mereka.

\section{Proses Belanja Online}

Berdasarkan teori perilaku konsumen (Kotler dan Amstrong 2011) proses konsumsi secara tradisional dibagi menjadi lima tingkatan yaitu pengenalan, pencarian informasi,evaluasi,pembelian, dan perilaku pasca pembelian. Hal ini terkait dari informasi dan promosi produk yang dibutuhkan oleh konsumen yang berasal dari periklanan online, informasi dari kolega, teman dimana pada kondisi sebelumnya (proses konsumsi) konsumen telah banyak menghabiskan waktu dan uang dalam proses pencarian tersebut.

Menurut Harahap dan amanah (2018) belanja online adalah aktivitas transaksi elektronik melalui toko online yang secara langsung terkoneksi melalui media seperti laptop, smartphone,pc/computer dan lainnya sesuai kebiasaan mereka untuk mencari apa keinginan mereka terkait kebutuhan harian, hobby dan sebagainya.

\section{Penelitian Terdahulu}

Dalam penelitian Neha.S (2018) menjelaskan persepsi konsumen dalam berbelanja online bahwa anak muda (20-25 tahun) lebih cenderung aktif melakukan belanja online dibandingkan orang berusia lanjut, kemudian untuk produk buku pada toko online lebih mendapatkan harga murah dibandingkan toko buku secara nyata. 
Penelitian Vikas dan Vinod Kumar (2017 dari hasil survey 100 orang ditemukan bukti yang menggambarkan persepsi konsumen dalam berbelanja online terkait hubungan yang kuat dengan demografi.

Hasil penelitian Mohamad Anisur Rahman (2018) Consumer Buying Behaviour Towards Online Shoping :An Empirical Study On Dhaka City menjelaskan hasil survey tersebut dengan mengungkapkan bahwa masyarakat berbelanja secara online guna menghemat waktu, mengharapkan ketersediaan produk secara luas, baik pria maupun wanita sama-sama menginginkan home delivery yang instan dan mereka mencari informasi secara online dari internet dan jaringan sosial, dan mereka sangat perhatian terhadap fitur keamanan berbelanja (payment system)

\section{METODE PENELITIAN}

Populasi pada penelitian ini adalah masyarakat kota padang yang pernah melakukan transaksi bisnis online yang tersebar di berbagai daerah di dalam kota Padang yang jumlahnya 80 orang.

Sampel dalam penelitian ini berjumlah sebanyak 64 orang (diambil dengan tingkat kepercayaan/alpha 0,05). Jenis Penelitian menggunakan metode studi deskriptif melalui online survey kepada para responden dengan sampel berjumlah sebanyak 60 orang (valid) di kota Padang dalam bentuk Questionnaire dengan metode non probability sampling.

Variabel dalam penelitian ini ada lima yaitu: Pemilihan Aplikasi online shoping (Y), Faktor Personal $\left(\mathrm{X}_{1}\right)$, Faktor Budaya $\left(\mathrm{X}_{2}\right)$, Faktor Lingkungan $\left(\mathrm{X}_{3}\right)$ Faktor Sosial $\left(\mathrm{X}_{4}\right)$.

Teknik analisis data menggunakan analisis faktor dengan bantuan SPSS Versi 20 dengan asumsi : 1.Data berdistribusi normal, 2. nilai Kaiser Mayer Olkin measure of sampling adequacy (KMO MSA) lebih besar dari 0,50 dan nilai Bartlett Test of Sphericity (sig) lebih kecil dari 0,50 dan 3.ada hubungan atau korelasi yang kuat antar variabel

\section{HASIL DAN PEMBAHASAN}

4.1 Uji Normalitas Data

Uji Normalitas Kolmogrov Smirnov

.Tabel 4.1: Hasil Uji Normalitas Data

\begin{tabular}{|ll|r|}
\hline & & Unstandardized Residual \\
\hline $\mathrm{N}$ & & 60 \\
Normal Parameters(a,b) & Mean & .0000000 \\
& Std. & 2.74062749 \\
& Deviation & .067 \\
Most Extreme Differences & Absolute & .067 \\
& Positive & -.055 \\
Kolmogorov-Smirnov Z & Negative & .520 \\
Asymp. Sig. (2-tailed) & & .950 \\
\hline
\end{tabular}

Berdasarkan output tabel diatas nilai Asymp.Sig. (2-tailed) sebesar 0,950 lebih besar dari 0,05 maka disimpulkan data berdistribusi normal.

4.2 Deskripsi variabel dan Hasil penelitian 


\subsubsection{Variabel Aplikasi online}

Berdasarkan hasil questionaire 60 orang responden sebanyak 63,3\% didominasi oleh wanita dan sebanyak $36,7 \%$ adalah Pria ,dari hal ini dapat diketahui bahwa wanita di kota padang lebih banyak menggunakan media aplikasi online untuk bertransaksi bisnis dibandingkan para pria.

Sebanyak $81,7 \%$ bertindak sebagai pembeli dan $16,7 \%$ merangkap sebagai pembeli dan penjual pada aplikasi online yang mereka pilih dan hanya $1,6 \%$ sebagai penjual, hal ini bermakna penggunaan aplikasi online dikota padang pada masa pandemic covid19 benar-benar dimanfaatkan oleh masyarakat sebagai alat untuk berbelanja bukan untuk menjual produk.

Untuk kategori bidang usaha asal dari 60 responden pengguna aplikasi online hanya 59 responden yang terdefinisi secara jelas. Dimana sebanyak $42 \%$ berasal dari kalangan masyarakat umum (wiraswasta), 16,9\% (lainnya),15,3\% akademisi, 11,9\% berasal dari pemerintahan (PNS), Komunitas sebanyak $10,2 \%$ dan dari media berjumlah hanya sebanyak 3,3\%

Dari Total 60 responden untuk kategori pilihan aplikasi belanja online untuk kota padang yang terbesar adalah aplikasi Shopee dengan 48,3\%. Kemudian sebanyak 31,7\% memilih aplikasi online lain yang tidak termasuk pada pilihan pertanyaan. Aplikasi tokopedia sebanyak $11,7 \%$ dan bukalapak sebanyak 8,3\%.Dari kondisi ini dapat disimpulkan market place bukalapak dan tokopedia masih kurang sekali jumlah pemakainya dikota padang dibandingkan aplikasi online lainnya yang menempati posisi nomor dua setelah aplikasi Shopee.

Berdasarkan kategori historis penggunaan aplikasi online di Kota padang sebanyak 26,7\% pengguna aplikasi bukalapak baru menggunakan aplikasi tersebut kurang dari satu tahun,selanjutnya pengguna aplikasi Tokopedia sebanyak $38,2 \%$ baru menggunakannya selama 1s/d 2 tahun. Untuk pengguna aplikasi Shopee sebanyak 26,7\% telah memakai aplikasi ini antara 3 s/d 5 tahun dan sebanyak $8,3 \%$ yang memilih aplikasi selain bukalapak, shopee dan tokopedia telah menggunakan aplikasi pilihannya telah lebih 5 tahun.

Terkait dengan faktor utama yang menjadi orientasi penggunaan aplikasi online tersebut sebanyak 45\%menginginkan kepraktisan /kemudahan penggunaan. Sebanyak 25\% menyukai fitur pencarian jenis barang yang luas. Sebanyak 18,3\% menginginkan barang dengan harga wajar. Sebanyak 8,3\% mementingkan fitur keamanan yang lengkap sebanyak 3,3\% menginginkan respon admin yang cepat dan hanya $0,1 \%$ yang peduli dengan tampilan yang menarik untuk keselurhan pilihan aplikasi online.

Selanjutnya untuk kategori siapa yang mendorong keiginan untuk menggunakan aplikasi online sebanyak 53,3\% berasal dari diri sendiri,sebanyak $15 \%$ karena melihat iklan internet, sebanyak 16,7 berasal dari preferensi keluarga,sebanyak $11,7 \%$ preferensi teman dan 3,3\% dari faktor lain yang belum diketahui. Artinya lebih dari 50\% masyarakat kota padang lebih suka mencoba dan mencari pengalaman sendiri dalam menggunakan aplikasi online dibandingkan preferensi lainnya.

\subsubsection{Variabel Faktor Personal}

Faktor Personal menggambarkan karakter psikologis manusia yang dipengaruhi oleh pribadi seseorang diantaranya yaitu umur pengalaman, pekerjaan, situasi ekonomi, gaya hidup dan sebagainya.

Berdasarkan hasil questionnaire dari 60 orang responden terkait Faktor personal sebanyak $40 \%$ berumur $30 \mathrm{~s} / \mathrm{d} 39$ tahun, sebanyak $25 \%$ berumur $20 \mathrm{~s} / \mathrm{d} 29$ tahun, 18,3\% berumur diatas 50 tahun, $15 \%$ berumur $40 \mathrm{~s} / \mathrm{d} 49$ tahun, dan hanya 1,7\% berumur dibawah 20 tahun, artinya sebagian besar pengguna aplikasi online berasal dari responden yang di bawah umur 50 tahun dan diatas 20 tahun. 
Terkait dengan aspek memiliki pengalaman berbelanja secara online dari 60 orang responden sebanyak $81,7 \%$ memiliki pengalaman dibawah 5 tahun, sebanyak $10 \%$ diatas 5 tahun dan hanya 8,3 $\%$ yang belum memiliki pengalaman bertransaksi secara online.

Pada aspek kecendrungan mengakses internet setiap harinya untuk pencarian informasi seputar produk yang akan dibeli atau dijual lewat aplikasi online, sebanyak 36,7\% kurang dari 1x sehari mengakses internet, sebanyak 35\% responden mengakses 1 s/d 3 kali sehari, 15\% mengakses internet lebih dari 5 kali sehari dan sebanyak 13,3\% mengakses informasi di internet $3 \mathrm{~s} / \mathrm{d} 5$ kali sehari.

Untuk waktu mengakses aplikasi online dari 60 responden sebanyak 56,7\% menjawab tidak punya waktu khusus dalam menggunakan aplikasi online ini, artinya responden ini tergolong orang yang mengakses lewat smartphone/tablet dan lebih mobile di luar ruangan. Sebanyak 33\% mengakses pada waktu malam hari,5\% siang hari dan 5\% sore hari. Untuk pemilihan media elektronik yang digunakan untuk bertransaksi online sebanyak $96,7 \%$ memilih smartphone sebagai piranti, penggunaan PC/Laptop sebanyak 5\% dan tablet 3,3\%. Kemudian pada hitungan transaksi online dalam satu bulan seabnyak $65 \%$ bertransaksi kurang dari 2 kali,sebanyak $25 \%$ bertransaksi 2 s/d 5kali dan $10 \%$ lebih dari 5 kali bertransaksi dalam satu bulan.

Selanjutnya terkait dengan pernyataan alasan kenapa mau berbelanja dengan aplikasi online sebanyak 47,5\% menyatakan sangat setuju dengan adanya bukti-bukti transaksi akan membuat mereka nyaman dalam bertransaksi online, $40,7 \%$ menjawab setuju, dan 11,9\% menjawab tidak setuju,

\subsubsection{Faktor Budaya}

Faktor budaya berisi nilai-nilai dan kebiasaan individu dari persepsi, preferensi dan perilaku seorang individu, berdasarkan hasil questionnaire 60 orang responden cenderung berbelanja produk pakaian (tekstil) dimasa pandemi Covid19 yaitu sebanyak 44,8\%, hal ini menjadi sebuah temuan besar di kota Padang dimana ketika pandemi biasanya orang-orang akan lebih banyak berdiam di rumah dan membutuhkan supply bahan harian, makanan dan obat-obatan. Namun begitu sebanyak 37,9\% (lainnya) belum terdefinisi jenis produk yang dibeli.produk sepatu dan digital/elektonik jumlahnya sama yaitu sebanyak $15,5 \%$, produk buku $12,1 \%$ dan kosmetik serta makanan dan obat sama menempati angka $8,6 \%$

Kemudian aspek budaya lain yakni orientasi pemberian rekomendasi kepada orang lain jika diangga puas dengan kondisi yang dirasakan oleh masing responden terkait aplikasi belanja online sebanyak 63,3\% setuju mempromosikan aplikasi belanja online yang dianggap bagus dan memuaskan, $31,7 \%$ memilih sangat setuju dengan pernyataan ini dan hanya 5\% yang menyatakan tidak setuju.

\subsubsection{Faktor Lingkungan}

Aspek dalam faktor ini adalah terkait fitur aplikasi, desain yang digunakan, layanan aftersales, kualitas informasi dan sebagainya seputar lingkungan market place yang menjadi pilihan responden

Dari hasil questionnaire 60 orang responden pada aspek fitur aplikasi sebanyak 28,3\% buyer (pembeli) memilih toko/seller dengan tingkat penjualan terbanyak,

kemudian sebanyak $25 \%$ responden lebih memilih seller dengan komentar yang positif dari buyer. Selanjutnya sebanyak $8,3 \%$ responden memilih seller dengan reputasi yang terjaga dengan baik serta seller yang menjual barang-barang berkualitas, sebanyak 3,3\% memilih alasan lainnya dan sebanyak 3,3\% memilih seller yang memiliki ketersediaan kelengkapan barang. Dan hanya seabnyak $1,7 \%$ yang memilih seller/toko dengan harga bersaing 
pada aspek kualitas promosi sebanyak $40 \%$ responden memilih seller dengan diskon khusus yang menarik. Kemudian sebanyak 20\% memilih promosi dari seller sebanyak 18,3\% responden memilih seller/toko yang menjual dengan harga murah. Sebanyak 6,7\% responden memilih seller yang memberikan penawaran harga (pada aplikasi) dan sebanyak 15\% memilih alasan lain.

Selanjutnya pada aspek desain/tampilan aplikasi sebanyak 56,7\% responden setuju jika tampilan /desain sangat penting ketika bertransaksi, sebanyak $41,7 \%$ berasums sangat penting dan hanya $1,7 \%$ yang menyatakan tidak setuju dengan pernyataan ini.

Selanjutnya pada komparasi antara beberapa seller yang ada pada aplikasi online yang dipilih oleh responden terkait historis bisnis transaksi dari 60 responden sebanyak 53,3\% menyatakan tidak setuju lebih memilih seller yang baru berjualan dibandingkan yang sudah lama berjualan, sebanyak $26,7 \%$ menyatakan setuju,13,3\% memilih sangat setuju dan 6,7\% menyatakan tidak setuju.

Kemudian terkait persepsi dampak negatif buyer terkait berbelanja melalui aplikasi online sebanyak $65 \%$ responden malas bertransaksi karena takut terbeli barang palsu, sebanyak $15 \%$ mengeluhkan pengiriman yang tidak tepat waktu/lama, kemudian sebanyak $10 \%$ mengeluhkan layanan after sales yang kurang baik dan informasi pribadi yang tidak terjaga.

Bertolak belakang dari dampak negatif, secara positif responden juga memberikan penilaian yang baik tentang penggunaan aplikasi online yaitu menghemat waktu dan bisa memantau ketersediaan produk secara cepat mendapatkan persentase sebesar $38,3 \%$, ini yang menjadi salah satu keunuggualan utama berbelanja online, kemudian sebanyak $28,3 \%$ lagi memilih harga yang murah, 20\% mengemukakan kemudahan bertransaksi ,kemudian10\% berpendapat detailnya informasi produk dan sebanyak 3,3\% mengemukakan pelayanan yang cepat.

Selanjutnya terkait hal lainya yakni situasi yang sulit yang sering ditemui oleh buyer maupun seller dimana sebanyak $43,3 \%$ buyer kapok berbelanja dengan alasan produk tidak bisa dikembalikan/diuangkan,28,3\% tidak menyukai seller yang mendapat komentar negative dari buyer lain,20\% mengeluhkan sikap seller yang kurang ramah, sebanyak 1,7\% mengatakan sulit untuk melakukan pembayaran dan $6,7 \%$ memberikan alasan lain diluar hal tersebut.

\subsubsection{Faktor Sosial}

Faktor sosial beimplikasi pada relasi keluarga, komunitas, media sosial yang dampaknya mempengaruhi keputusan konsumen untuk memilih sesuatu sesuai dengan apa yang ia persepsikan, dari 60 responden terkait faktor sosial, komentar yang ada pada aplikasi sebanyak 63,3\% responden meyatakan bahwa komentar yang masuk ke dalam aplikasi setelah terjadinya pembelian baik itu komentar positif atau feedback negative akan sangat mempengaruhi niat pembelian konsumen di tahap selanjutnya. Kemudian sebanyak 31,7 \% sangat memperhatikan komentar yang masuk dan sebagian responden lain sebanyak 5\% cukup mengabaikan komentar dan lebih memilih seller yang sudah ternama.

\subsection{Hasil Analisis dan Pengolahan Data Kuantitatif}

Analisis Faktor dalam penelitian ini menggunakan metode KMO-MSA (Kaiser-Meyer-Olkin Measure of Sampling Adequacy)

Menurut Imam Ghozali (2009:307) uji KMO dilakukan untuk mengetahui apakah faktor-faktor di dalam penelitian valid atau tidak dimana angka KMO dan Bartlett test harus diatas 0,5 dengan probabilitas sig. $<0,05$ maka variabel penelitian tidak dapat dianalisis lebih lanjut dan jika probabilitas sig. $>0,05$ maka variabel penelitian dapat dianalisis lebih lanjut.

Selanjutnya menurut Imam gozali (2011:304) untuk melihat variabel-variabel mana yang layak untuk mengetahui faktor-faktor yang dijadikan sebagai faktor analisis mempunyai korelasi yang 
kuat atau tidak dengan nilai lebih besar atau sama dengan 0,5. jika nilainya lebih besar atau sama dengan 0,5 maka semua faktor pembentuk variabel tersebut telah valid dan tidak ada faktor yang direduksi.

Pada bagian anti image correlation yang pertama kali dikeluarkan adalah variabel yang memiliki nilai MSA paling kecil dan kurang dari 0,5 , besarnya angka MSA berkisar antara 0 dan 1 dengan kriteria sebagai berikut :

1.MSA=1, item tersebut dapat diprediksi tanpa kesalahan oleh item lain

2.MSA>0,5, item masih bisa diprediksi dan dianalisis lebih lanjut

3.MSA $<0,5$, item tidak bisa diprediksi dan dianalisis lebih lanjut

Tabel 4.2 Nilai KMO dan Bartlett

\begin{tabular}{|ll|r|}
\hline Kaiser-Meyer-Olkin Measure of Sampling & .499 \\
Adequacy. & \\
Bartlett's Test of Sphericity & Approx. Chi- & 6.171 \\
& Square & 6 \\
& df & .404 \\
\hline
\end{tabular}

Berdasarkan Tabel 4.2 diatas dengan melihat nilai KMO-MSA (Kaiser-Meyer-Olkin Measure of Sampling Adequacy) sebesar 0,499<0,50 dan nilai Bartlett Test of Sphericity (Sig.) 0,404>0,05 maka pada langkah awal terdapat hambatan karena prasyarat untuk melanjutkan nilai KMO MSA harus $>0,50$.

Dengan demikian dikeluarkan 1buah variabel yakni yang memiliki nilai anti image terkecil dari 4 variabel faktor.

Tabel 4.3

\section{KMO and Bartlett's Test}

\begin{tabular}{|l|r|}
\hline $\begin{array}{l}\text { Kaiser-Meyer-Olkin Measure of Sampling } \\
\text { Adequacy. }\end{array}$ & .521 \\
Bartlett's Test of Sphericity & $\begin{array}{l}\text { Approx. Chi- } \\
\text { Square }\end{array}$ \\
& df \\
Sig. & 4.649 \\
\end{tabular}

Berdasarkan table diatas setelah dikeuarkan variabel faktor personal maka nilai KMO-MSA adalah $0,521>0,50$ sehingga item faktor variabel lain masih bisa diprediksi. 
Tabel 4.4 Nilai MSA

\begin{tabular}{|c|c|c|c|c|}
\hline & & FaktorBudaya & $\begin{array}{c}\text { Faktor } \\
\text { Lingkungan }\end{array}$ & FaktorSosial \\
\hline \multirow[t]{3}{*}{ Anti-image Covariance } & FaktorBudaya & .983 & -.114 & .020 \\
\hline & FaktorLingkungan & -.114 & .924 & .228 \\
\hline & FaktorSosial & .020 & .228 & .937 \\
\hline \multirow[t]{3}{*}{ Anti-image Correlation } & FaktorBudaya & $.566^{\mathrm{a}}$ & -.119 & .021 \\
\hline & FaktorLingkungan & -.119 & $.514^{\mathrm{a}}$ & .245 \\
\hline & FaktorSosial & .021 & .245 & $.518^{\mathrm{a}}$ \\
\hline
\end{tabular}

a. Measures of Sampling Adequacy(MSA)

Dari tabel diatas dapat dilihat bahwa variabel faktor personal sudah dikeluarkan dimana anti image matrices berguna mengetahui dan menentukanvariabel mana saja yang layak dipakai dalam analisis faktor. Diketahui nilai masing-masing MSA yaitu :

1.Faktor Budaya sebesar 0,566

2.Faktor Lingkungan sebesar 0,514

3.Faktor Sosial sebesar 0,518

Dengan demikian langkah kedua dari analisis ini dapat diteruskan karena nilai MSA>0,50

Tabel 4.5 Nilai Communalities

\begin{tabular}{|l|c|r|}
\hline & Initial & $\begin{array}{c}\text { Extractio } \\
\mathrm{n}\end{array}$ \\
\hline Faktor Budaya & 1.000 & .201 \\
Faktor & 1.000 & .597 \\
Lingkungan & 1.000 & .505 \\
\hline
\end{tabular}

Tabel 4.5 diatas menunjukan nilai variabel yang diteliti apakah mampu untuk menjelaskan faktor atau tidak, variabel dianggap mampu menjelaskan faktor jika nilai extraction lebih besar dari 0,50. Dapat dilihat dari tabel diatas variabel faktor budaya tidak dapat dipakai untuk menjelaskan faktor karena nilai extraction $0,201<0,50$

Tabel 4.6 Total Varian Explained

Total Variance Explained

\begin{tabular}{|l|r|r|r|r|r|r|}
\hline & \multicolumn{3}{|c|}{ Initial Eigenvalues } & \multicolumn{3}{|c|}{ Extraction Sums of Squared Loadings } \\
\cline { 2 - 7 } Component & \multicolumn{1}{|c|}{ Total } & $\%$ of Variance & Cumulative \% & \multicolumn{1}{|c|}{ Total } & $\%$ of Variance & Cumulative \% \\
\hline 1 & 1.304 & 43.466 & 43.466 & 1.304 & 43.466 & 43.466 \\
2 & .958 & 31.940 & 75.406 & & & \\
3 & .738 & 24.594 & 100.000 & & & \\
\hline
\end{tabular}

Nilai total variance explained menunjukan

nilai masing-masing variabel yang dianalisis dalam penelitian ini ada 3 variabel berarti ada 3 komponen yang dianalisis, pada tabel 4.6 nilai initial eigenvalue menunjukan faktor yang terbentuk, sedangkan dibagian extract sum of squared menunjukan jumlah variasi atau banyaknya faktor yang dapat terbentuk. Dari tabel terdapat 1 faktor yang terbentuk dari 3 variabel yang dianalisis, dimana syarat untuk menjadi sebuah faktor nilai eigenvalue harus $>1$. Nilai Eigenvalue komponen 1 sebesar 
1,304 atau >1 maka menjadi faktor 1dan mampu menjelaskan $43.466 \%$ variasi, sedangkan untuk komponen 2 dan 3 tidak dihitung karena nilai eigenvalue nya $<1$.

Tabel 4.7 Component Matrix

\begin{tabular}{|l|r|}
\hline & Component \\
\hline & 1 \\
\hline FaktorBudaya & .448 \\
FaktorLingkungan & .773 \\
FaktorSosial & -.711 \\
\hline
\end{tabular}

Tabel 4.7 menjelaskan nilai korelasi atau hubungan masing-masing variabel dengan dengan faktor yang akan terbentuk, dari data terlihat hanya 1 faktor yang terbentuk yaitu nilai korelasi variabel ini dengan faktor 1 adalah sebesar $0,448,0,773$ dan $-0,711$

\section{E. KESIMPULAN}

Dari ke empat faktor yakni faktor personal, faktor budaya, faktor lingkungan dan faktor sosial variabel yang dapat diprediksi adalah faktor lingkungan dan faktor budaya namun hanya dapat terbentuk nilai korelasi satu faktor saja, sehingga rotated component matrik untuk menjelaskan variabel tidak dapat terbentuk.

Perbandingan aktivitas antara buyer dan seller di masa pandemi aktivitas transaksi bisnis lebih besar mengarah kepada tingkat konsumsi (pembelian) melalui aplikasi online dibandingkan dengan aktivitas penjualan dengan menggunakan aplikasi online

\section{F. REFERENSI}

Amanah, D., Harahap, D. A., \& Lisnawati, D. (2017). Exploring Online Purchase Decision Among University Students in Indonesia. Journal of Humanities and Social Science, 22(5), 72-77. https://doi.org/10.9790/0837-2212057277

Amanah, D., \& Harahap, D. A. (2018b). Examining The Effect of Product Assortment and Price Discount Toward Online Purchase Decision of University Student in Indonesia. Jurnal Manajemen Dan Kewirausahaan, 20(2), 99-104. https://doi.org/10.9744/jmk.20.2.99

Damiati, Dkk. (2017). Perilaku Konsumen. Raja Grafindo Persada: Kota Depok

https://databoks.katadata.co.id/datapublish/2020/09/21/peta-persaingan-e-commerce-indonesiapada-kuartal-ii-2020

Ghozali, Imam. 2009. “Aplikasi Analisis Multivariate dengan Program SPSS “. Semarang : UNDIP.

Mohammad Anisur Rahman, Md. Aminul Islam, Bushra Humyra Esha, Nahida Sultana \& Sujan Chakravorty | (2018) Consumer buying behavior towards online shopping: An empirical study on Dhaka city, Bangladesh, Cogent Business \& Management, 5:1, 1514940

Kotler, P. and Keller, K. L. (2012). Marketing Management (fourteenth edition). USA:Pearson. Kotler,Phillip and Armstrong, Gary (2011,) Principle of Marketing $14^{\text {th }}$ ed Publisher Pearson Prentice Hallhttps://www.statista.com/statistics/869700/indonesia-top-10-e-commerce-sites/ 
Sharma N. (2018), Consumers' perception on online shopping, International Journal of Academic Research and Development ISSN: 2455-4197, Volume 3; Issue 1; January 2018; Page No. 833-837.

Vikas \& Kumar V. (2017), "A Study on Consumer Perception toward Online Shopping”, IOSR Journal of Business and Management (IOSR-JBM) e-ISSN: 2278-487X, p-ISSN: 2319-7668. Volume 19, Issue 8. Ver. I. (August 2017), PP 32-35. 